\title{
Enclosure
}

\section{PALESTINIAN LANDSCAPES IN}

A HISTORICAL MIRROR

Gary Fields

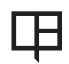

U NIVERSITY OF CALIFORNIA PRESS 
University of California Press, one of the most distinguished university presses in the United States, enriches lives around the world by advancing scholarship in the humanities, social sciences, and natural sciences. Its activities are supported by the UC Press Foundation and by philanthropic contributions from individuals and institutions. For more information, visit www.ucpress.edu.

University of California Press

Oakland, California

() 2017 by The Regents of the University of California

Library of Congress Cataloging-in-Publication Data

Names: Fields, Gary, 1954- author.

Title: Enclosure : Palestinian landscapes in a historical mirror / Gary Fields. Description: University of California Press : Oakland, California, [2017] | Includes bibliographical references and index.

Identifiers: LCCN 2017002268 (print) | LCCN 2017011093 (ebook) | ISBN 978052029104 I (cloth : alk. paper) | ISBN 9780520291058 (pbk. : alk. paper) | ISBN 978052096492I (ebook)

Subjects: LCSH: Land tenure-Middle East.

Classification: LCC HD850.F535 2017 (print) | LCC HD850 (ebook) | DDC 333.3/15694-dc23

LC record available at https://lccn.loc.gov/2017002268

Manufactured in the United States of America

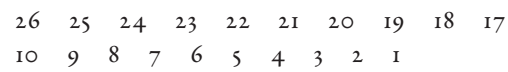

